\title{
Museum specimens as Noah's Arc of lost genes. The case of a rhinoceros from Sumatra in the Zoological Museum Hamburg
}

\author{
Matthias Glaubrecht ${ }^{1}$, Marco T. Neiber ${ }^{1}$ \\ 1 Department of Animal Diversity, Center of Natural History (CeNak), University of Hamburg, Martin-Luther-King-Platz 3, 20146 Hamburg, Germany
}

http://zoobank.org/4200B378-6B3B-48E0-9472-C5D77C4EAF0C

Corresponding author: Matthias Glaubrecht (matthias.glaubrecht@uni-hamburg.de)

Received 10 August 2017

Accepted 14 December 2017

Published 22 December 2017

Academic editor:

Andreas Schmidt-Rhaesa

\section{Key Words}

Asian rhinoceros

biohistory

mitochondrial gene fragment

molecular genetics

Javan rhinoceros

Rhinoceros sondaicus

Sumatran rhinoceros

Dicerorhinus sumatrensis

Centrum für Naturkunde (CeNak)

\begin{abstract}
Understanding past and present genetic diversity, in particular in endangered species such as the rhinoceroses, is of paramount importance for a series of aspects in natural history, evolutionary systematics and conservation. As it turned out from several recent studies even in eminent museum specimens the historical context including its provenance often remains unresolved. At the same time modern molecular genetic techniques make this material more and more available also for integrative studies. With probably less than fifty extant specimens, among the Asian rhinoceroses the Javan rhinoceros, Rhinoceros sondaicus, is one of the most critically endangered mammal species, rendering also each of its rare museum specimens of great significance. We here apply available DNA isolation and sequencing techniques to a horn of a specimen housed at the Zoological Museum in Hamburg with indication as to derive from the extinct conspecific Sumatra population. In comparison with already existing mitochondrial gene fragment sequence data of Asian rhino populations, we were able to verify the identification of this particular museum specimen as of the nearly equally rare Sumatran rhinoceros, Dicerorhinus sumatrensis, instead as of the extremely rare $R$. sondaicus.
\end{abstract}

\section{Introduction}

Not only people but also museum specimens have a life history that on the one hand can help to reconstruct past processes of gaining knowledge and on the other hand contribute to a currently emerging new discipline, to be dubbed biohistory; for case studies see e.g. Glaubrecht and Dohle (2012) and Glaubrecht et al. (2013a).

Untapped and underutilized for long, museum objects most recently gained a new importance in attempts to reconstruct environmental history in particular with the application of novel molecular genetic techniques. Advances in this field, in particular new protocols for isolating DNA from preserved materials and next generation sequencing, renders museum material also a kind of Noah's Arc for lost genes as it has the potential to mirror the spectrum and assortment of biodiversity on the molecular and genetic level.

Therefore, in addition to help for example in reconstructing species' distributions from museum records (for an example from malacology see e.g. Glaubrecht and Podlacha 2010), the study of molecular genetic differentiation of species represented in museum tissue samples allows to largely expand the data basis by new and otherwise non-available data points (e.g. Wandeler et al. 2007; Habel et al. 2014; Glaubrecht et al. 2013b). Groenenberg et al. (2012) recently described this for the case study of a historical specimen of an Asian rhinoceros with formerly questionable species identity, which by virtue of DNA sequencing was confirmed as of Rhinoceros unicornis, not $R$. sondaicus.

We here report on research into the records in the museum archives of the Zoological Museum Hamburg 
(ZMH), following hints of the existence of a horn of arguably the most rare and endangered Javan rhinoceros from the Indonesian island of Sumatra. Two species of Asian rhinoceros are known to exist there, viz. the Sumatran rhinoceros, Dicerorhinus sumatrensis, first described scientifically by the German naturalist Gotthelf Fischer von Waldheim (1771-1853) in the year 1814, and the Javan rhinoceros, Rhinoceros sondaicus Desmarest, 1822, originally described from a specimen found in Java (for clarification on the locus typicus see Rookmaaker 1982). Both species are today extremely rare and highly endangered. The Sumatran rhinoceros is currently known to exist only with perhaps less than one hundred animals in total in three small populations on Sumatra, viz. in the Gunung Leuser National Park, the Bukit Barisan Selatan National Park and the Way Kambas National Park, and one population on Borneo in a rhino sanctuary in the Tabin Wildlife Reserve in East Kalimantan (Foose and van Strien 1997).

The Javan rhinoceros $R$. sondaicus was formerly widely distributed in mainland Asia from the Sunderbans in Bangladesh across Myanmar, Thailand, Laos, Cambodia, Vietnam and peninsular Malaysia to the two larger Sunda islands Sumatra and Java. Described as a subspecies, $R$. sondaicus floweri Gray, 1868 (see Groves 1967), R. sondaicus from Sumatra is only known historically where it had disappeared from almost its entire range by the early $20^{\text {th }}$ century (Groves 1967). Most recently a very small population in Cat Tien National Park in Vietnam went extinct when in April 2010 poachers killed the last single animal known from Asian mainland. Today, this species is only extant with one highly endangered population in the Ujung Kulon National Park in Western Java where only about 40 to an estimated maximum of around 60 animals survived (International Rhino Foundation 2010). Thus, the Java rhinoceros has to be considered as one of the most rare and highly threatened species among the endangered mammals in particular.

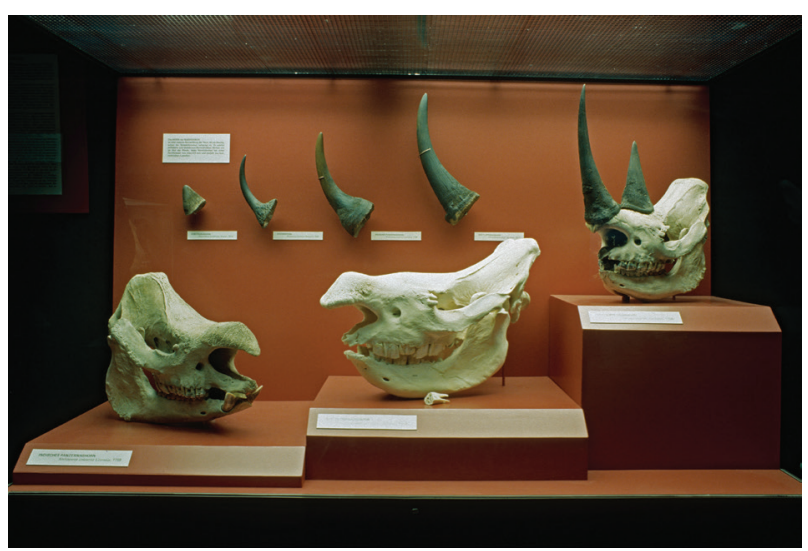

Figure 1. The horns and skulls, respectively, of five rhinoceroses as presented on display in the exhibition of the Zoological Museum in Hamburg since the 1980s. Among them was also a horn of the extremely rare Rhinoceros sondaicus from West Java. The complete set of horns was stolen from this showcase in June 2011 [photograph courtesy of Harald Schliemann].
While there are no animals known to be kept in captivity of any zoo worldwide for about the last century, only very rarely specimens are available from museum collections. We are aware of only few $R$. sondaicus and $D$. sumatrensis, among them specimens in the Zoological Museum in Hamburg. Unfortunately, this museum, among other German and European collections, fell victim to a concerted theft of rhinoceros horns in June 2011. A total of five horns and skulls, respectively, of the two African species and all three Asian species of rhinoceroses were stolen, among them one specimen (ZMH 10617) of the extremely rare Javan rhinoceros, shot c. 1920 in West Java by a hunter named "von Stein", with the horn sold by the Dutch agent H. L. Blonk to the Zoological Museum in Hamburg in July 1984, as given in the archival records of the museum (Fig. 1).

Investigation of the catalogues of the Department of Mammalogy and files in the museum archives revealed, however, that in addition a second horn labelled as originating from a $R$. sondaicus (ZMH S 8070) specimen was inventorized even earlier in this museum (indicated by the lower catalogue number), with a precise location given as on Sumatra (Fig. 2). This island was long assumed to be the locus typicus for the species, albeit this problem was recently settled by Rookmaaker (1982) who clarified that the type specimen was collected on Java in 1821 by the French naturalist Pierre-Médard Diard (1794-1863).

Even more important, apparently no genetic information is available for the Sumatra population of the Javan rhinoceros, while in contrast DNA sequence fragments of the $12 \mathrm{~S}$ rRNA and the non-coding D-loop are available from specimens from the highly endangered West Java population as well as from the now extinct populations in Vietnam (Fernando et al. 2006).

Based on mtDNA sequence data it was the aim of this latter study to evaluate the genetic divergence between these two (then still extant) populations as well as the ex-

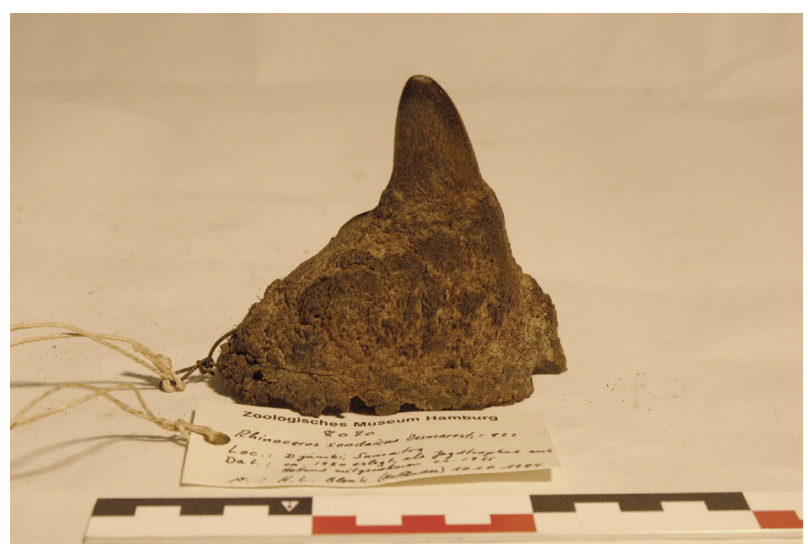

Figure 2. The specimens ZMH S 8070 of the Zoological Museum Hamburg, labelled as "Rhinoceros sondaicus Demarest, 1822", with location given as Djambi, Sumatra. [photograph courtesy of Thomas Kaiser]. 
tent of genetic variation present in each population and species. As to the genetic diversity of the Javan rhinoceros they found three distinct haplotypes of considerable genetic variation, even among the very restricted population in Ujung Kulon National Park in West Java. This might reflect the originally largely fragmented range on the Southeast Asian mainland and the Sunda islands on the one hand and the re-colonization of Western Java following the volcanic eruption and destruction of Krakatau in 1883 as hypothesized by van Strien and Rookmaaker (2010) based on other evidence.

Consequently, it is evident that in particular in rare species any museum specimen is of highest interest for molecular genetic studies. Therefore, we decided to apply DNA isolation techniques for historical material in order to look into the identification and origin of the museum material of $R$. sondaicus at hand.

\section{Material and methods}

\section{Sampling, DNA isolation and amplification}

This account is based on the examination of a horn from a putative $R$. sondaicus specimen (S 8070) in the collection of the Zoological Museum Hamburg (ZMH), which is an integral part of the in 2014 newly founded Centrum für Naturkunde (CeNak) of the Universität Hamburg (see Glaubrecht 2017).

Dried tissue from two different parts of this isolated horn (ZMH S 8070) was collected in sterile $1.5 \mathrm{ml}$ tubes. To avoid potential contamination as much as possible, outer adhering tissue layers were removed with sterile pincers prior to tissue collection. The tissue was then digested overnight and the DNA isolated according to the protocol for historical samples as detailed in Neiber et al. (2017), which is based on a high salt protocol by Sokolov (2000) in combination with a spin column-based solid phase extraction method.

Partial sequences of the mitochondrial 12S rDNA were amplified by polymerase chain reaction (PCR) using the primer pair RH-12S-F (5'-GCC YAG ATG AGM CYA CCA RCT-3'; Fernando et al. 2006) plus 12SC (5'-TAG AGC ACC GCC AAG TCC TTT G-3'; Titus and Larson 1996). Amplifications were performed in $25 \mu \mathrm{l}$ volumes containing $2.5 \mu \mathrm{l} 10 \times$ Dream Taq Green amplification buffer (Thermo Fisher Scientific Waltham, MA, USA), $1 \mu \mathrm{dNTP} \operatorname{mix}(5 \mathrm{mM}$ each, biolabproducts, Bebensee, Germany), $1 \mu \mathrm{l}$ of each primer $(10 \mu \mathrm{M}), 0.2 \mu \mathrm{l}$ Dream Taq DNA polymerase (Thermo Fisher Scientific), $1 \mu \mathrm{l}$

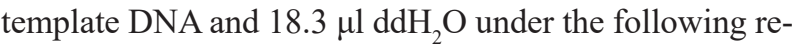
action conditions: an initial denaturation step at $94{ }^{\circ} \mathrm{C}$ for $2 \mathrm{~min}, 40$ PCR cycles $\left(94{ }^{\circ} \mathrm{C}\right.$ for $30 \mathrm{~s}, 55^{\circ} \mathrm{C}$ for $30 \mathrm{~s}, 72$ ${ }^{\circ} \mathrm{C}$ for $30 \mathrm{~s}$ ) and a final extension step at $72{ }^{\circ} \mathrm{C}$ for $5 \mathrm{~min}$. Prior to sequencing, PCR products were enzymatically cleaned up by adding $0.65 \mu$ FastAP thermosensitive alkaline phosphatase (Thermo Fisher Scientific) and $0.35 \mu \mathrm{l}$ exonuclease I (Thermo Fisher Scientific) to a $5 \mu \mathrm{l}$ volume of undiluted PCR mixture followed by an incubation step at $37{ }^{\circ} \mathrm{C}$ for $15 \mathrm{~min}$. The enzymes were inactivated at 85 ${ }^{\circ} \mathrm{C}$ for $15 \mathrm{~min}$. Both strands of amplified products from the two different parts of the horn were sequenced at Macrogen Europe Laboratory (Amsterdam, The Netherlands).

CHROMASPRO version 1.7.1 (Technelysium, Tewantin, Australia) was used to assemble forward and reverse sequence reads and the sequences from the two different parts of the horn were checked for mismatches.

In addition to the newly generated data, all available $12 \mathrm{~S}$ rDNA sequences for Rhinocerotidae from the previously published studies of Douzery and Catzeflis (1995), Xu et al. (1996), Xu and Árnason (1997), Tougard et al. (2001), Fernando et al. (2006), Willerslev et al. (2009) and Groves et al. (2010), in total 21 sequences, were downloaded from GenBank (www.ncbi. nlm.nih.gov/Genbank). Information on vouchers, locality data (if available) and GenBank accession numbers are listed in Table 1. To allow the position of the root to be inferred, 12S rDNA sequences of two perrisodactylan outgroups, the horse Equus caballus Linnaeus, 1758 (Xu and Árnason 1994; GenBank accession number: NC_001640) and tapir Tapirus terrestris (Árnason et al. 2008; GenBank accession number: AJ428947), respectively, were included in the analyses. Sequences were aligned with MAFFT (Katoh and Standley 2013) using the Q-INS-i iterative refinement algorithm and otherwise default settings.

The original alignment of the target $12 \mathrm{~S}$ rDNA fragment had a length of 498 base pairs (bp). Surprisingly, it was noticed that the sequences from the study of Fernando et al. (2006) lacked data in five variable regions of the aligned 12S rDNA fragment, i.e. between positions 155 and 164, 193 and 198, 290 and 294, 375 and 388 and 538 and 545 of the complete mitochondrial genome of D. sumatrensis (GenBank accession number FJ_905816; Willerslev et al. 2009). Since all other Rhinocerotidae possess a variable number of bases in these regions, it is assumed here that Fernando et al. (2006) erroneously uploaded trimmed sequences to the GenBank database. To avoid effects on phylogenetic reconstructions, these regions were therefore excluded from phylogenetic analyses. The resulting trimmed alignment for phylogenetic analyses had a length of $453 \mathrm{bp}$.

\section{Phylogenetic analyses}

Maximum Likelihood (ML) and Maximum parsimony (MP) searches as well as Bayesian Inference (BI) of phylogeny were used to reconstruct phylogenetic relationships. To select an evolutionary model for the ML and BI analyses, the $12 \mathrm{~S}$ rDNA sequence data set was analysed with PARTITIONFINDER version 1.1.1 (Lanfear et al. 2012). The Bayesian Information Criterion (BIC) was used to select among models.

Heuristic ML analyses were performed with the GARLI 2.1 (Zwickl 2006) using the best-fit model (HKY+ $\mathrm{G}$ model) suggested by PARTITIONFINDER. Support values were computed by bootstrapping with 1,000 pseudoreplicates. 
Table 1. Locality data and GenBank accession numbers for Rhinocerotidae 12S rDNA sequences used in this study.

\begin{tabular}{|c|c|c|c|c|c|}
\hline Taxon & Common name & Country & Locality & \begin{tabular}{|c|} 
GenBank accession \\
number (12S rDNA)
\end{tabular} & Reference \\
\hline Dicerorhinus s. sumatrensis & Sumatran rhinoceros & Indonesia & Riau and Bengkulu (Sumatra) & AY739616 & Fernando et al. (2006) \\
\hline Dicerorhinus s. sumatrensis & Sumatran rhinoceros & - & Captive & FJ905816 & Willerslev et al. (2009) \\
\hline Dicerorhinus s. sumatrensis & Sumatran rhinoceros & Indonesia & Djambi (Sumatra) & MG674188 & this study \\
\hline $\begin{array}{l}\text { Dicerorhinus sumatrensis } \\
\text { harrissoni }\end{array}$ & Sumatran rhinoceros & Malaysia & Sabah (Borneo) & AY739617 & Fernando et al. (2006) \\
\hline Coelodonta antiquitatis & Wooly rhinoceros & Russia & $\begin{array}{c}\text { Yakutia, Taimylyr village, } \\
\text { Olenyok River valley }\end{array}$ & FJ905813 & Willerslev et al. (2009) \\
\hline Rhinoceros unicornis & Indian rhinoceros & India/Nepal & Captive & AY739618 & Fernando et al. (2006) \\
\hline Rhinoceros unicornis & Indian rhinoceros & India/Nepal & Captive & X97336 & Xu et al. (1996) \\
\hline Rhinoceros sondaicus & Javan rhinoceros & - & $\begin{array}{l}\text { Collection of Oxford } \\
\text { University Museum for } \\
\text { Natural History (UK) }\end{array}$ & FJ905815 & Willerslev et al. (2009) \\
\hline Rhinoceros s. sondaicus & Javan rhinoceros & Indonesia & Ujung Kulon National Park & AY739620 & Fernando et al. (2006) \\
\hline Rhinoceros s. amnamiticus & Javan rhinoceros & Vietnam & Cat Tien National Park & AY739619 & Fernando et al. (2006) \\
\hline Ceratotherium simum & White rhinoceros & - & - & NC_001808 & Xu and Árnason (1997) \\
\hline Ceratotherium simum & White rhinoceros & - & - & X86942 & $\begin{array}{c}\text { Douzery and Catzeflis } \\
(1995)\end{array}$ \\
\hline Ceratotherium s. simum & $\begin{array}{c}\text { Southern white } \\
\text { rhinoceros }\end{array}$ & South Africa & Krüger National Park & AY739623 & Fernando et al. (2006) \\
\hline Ceratotherium s. cottoni & $\begin{array}{l}\text { Northern white } \\
\text { rhinoceros }\end{array}$ & $\begin{array}{l}\text { Democratic } \\
\text { Republic of } \\
\text { the Congo }\end{array}$ & Garamba National Park & AY739624 & Fernando et al. (2006) \\
\hline Ceratotherium s. cottoni & $\begin{array}{l}\text { Northern white } \\
\text { rhinoceros }\end{array}$ & $\begin{array}{l}\text { Democratic } \\
\text { Republic of } \\
\text { the Congo }\end{array}$ & Garamba National Park & FJ608806 & Groves et al. (2010) \\
\hline Diceros bicornis & Black rhinoceros & - & - & AJ245721 & Tougard et al. (2001) \\
\hline Diceros bicornis & Black rhinoceros & - & $\begin{array}{l}\text { Collection of Zoological } \\
\text { Museum, University of } \\
\text { Copenhagen (Denmark) }\end{array}$ & FJ905814 & Willerslev et al. (2009) \\
\hline Diceros b. michaeli & $\begin{array}{c}\text { Kenyan black } \\
\text { rhinoceros }\end{array}$ & Kenya & Solio Game Reserve & AY739621 & Fernando et al. (2006) \\
\hline Diceros b. michaeli & $\begin{array}{c}\text { Kenyan black } \\
\text { rhinoceros }\end{array}$ & Kenya & Solio Game Reserve & FJ608807 & Groves et al. (2010) \\
\hline Diceros b. cf. minor & Black rhinoceros & South Africa & - & AJ245721 & Tougard et al. (2001) \\
\hline Diceros b. minor & $\begin{array}{c}\text { Southern black } \\
\text { rhinoceros }\end{array}$ & Zimbabwe & Zambezi Valley & AY739622 & Fernando et al. (2006) \\
\hline Diceros b. minor & $\begin{array}{c}\text { Southern black } \\
\text { rhinoceros }\end{array}$ & Zimbabwe & Zambezi Valley & FJ608808 & Groves et al. (2010) \\
\hline
\end{tabular}

Bayesian Inference was performed using MRBAYES version 3.2.6 (Ronquist et al. 2012). Metropolis-coupled Monte Carlo Markov chain $\left(\mathrm{MC}^{3}\right)$ searches were run with four chains in two separate runs for 50,000,000 generations with trees sampled every 1,000 generations under default heating using the best-fit model (HKY+ G model) as suggested by the PARTITIONFINDER analysis. To ensure that the $\mathrm{MC}^{3}$ searches had reached stationarity and convergence, potential scale reduction factors close to 1 , average standard deviations of split frequencies $<0.01$ and estimated sample sizes above 200 from the MRBAYES output were used as diagnostics and the first 5,000,000 generations were discarded as burn-in.

Heuristic MP searches were conducted with PAUP* $4.0 \mathrm{~b} 10$ (Swofford 2002) with unordered characters, 100 random sequence addition replicates, the TBR branch-swapping, and gaps treated as missing data. Support for internal branches was assessed in PAUP* by nonparametric bootstrapping with 1,000 pseudoreplicates, using full heuristic searches with 10 random addition sequence replicates, TBR branch swapping, and one tree held at each step during stepwise addition.

Bootstrap support (BS) values from the MP and ML analyses as well as posterior probabilities (PP) from the $\mathrm{BI}$ analysis were mapped onto the BI $50 \%$ majority rule consensus tree with SUMTREES version 3.3.1, which is part of the DENDROPY 3.8.0 package (Sukumaran and Holder 2010). BS values $\geq 70$ and PP values $\geq 0.95$ were interpreted as positive support.

\section{Results}

\section{On the origin of the Hamburg rhinoceros specimen}

The specimen ZMH S 8070, a conical horn of about 15 $\mathrm{cm}$ length, by its number indicating the inventarisation in the early 1980s in the Hamburg Zoological Museum, is labelled as "Rhinoceros sondaicus Demarest, 1822", 
with location given as "Djambi, Sumatra" (Fig. 2). As additional information on date and origin it is noted: " $c a$. 1930 erlegt, als Jagdtrophäe nach Holland mitgenommen ca. 1965 " [i.e., shot around 1930, taken as hunting trophy to the Netherlands around 1965].

In the archives of the Department of Mammalogy we found a simple handwritten note, by the Dutch natural history agent and dealer H. L. Blonk, who sold several natural history objects to the Zoological Museum in Hamburg, stating the date October 10, 1984 for the delivery of three rhinoceroses at that time: in addition to one rhinoceros from South Africa, this note also lists one horn each from the Javan and the Sumatran rhinoceros, respectively, for both of which the same location is given as Djambi on Sumatra.

Apparently, this information was used to label the respective specimens by the then active collection technician (H. Schliemann, pers. comm.).

\section{Molecular results}

The sequences obtained from two different isolates from tissue adhering to the rhinoceros horn (ZMH S 8070) were identical and grouped with the Sumatran rhinoceros Dicerorhinus sumatrensis with very high support (PP: 0.99; BS (ML): 98; BS (MP): 100, Fig. 4) in all phylogenetic analyses, but not with the Javan rhinoceros $R$. sondaicus instead, as the label and documents from the museum's archives would suggest. A comparison of sequences showed a $100 \%$ identity with all available sequences of the Sumatran rhinoceros from GenBank with respect to the trimmed alignment and also with the untrimmed sequence of the Sumatran rhinoceros from the study of Willerslev et al. (2009) leaving no doubt on the correct molecular identification of the $\mathrm{ZMH}$ specimen. Pairwise genetic p-distances within the African white rhinoceros and black rhinoceros ranged from 0 to $1.8 \%$ between specimens, while the p-distances between Javan rhinoceros specimens were less than $0.9 \%$. The two included sequences of the Indian rhinoceros were identical.

All three phylogenetic analyses recovered the monophyly of Rhinocerotidae with high support (PP: 1.00; BS (ML): 97; BS (MP): 100, Fig. 4). The monophyly of the African rhinoceroses $C$. simum (PP: 0.86; BS (ML): 72; BS (MP): 95) and D. bicornis (PP: 1.00; BS (ML): 98; BS (MP): 100) was recovered in the ML and MP analyses but not significantly in the BI analysis (PP: 0.90; BS (ML): 74; BS (MP): 75, Fig. 4). The sister group relationship of the Javan rhinoceros and the Indian rhinoceros was recovered with maximal support in all three analyses. However, the monophyly of the Javan rhinoceros was only supported in the ML and MP analyses (PP: 0.91; BS (ML): 74; BS (MP): 97, Fig. 4). The Sumatran rhinoceros was grouped together with the extinct woolly rhinoceros
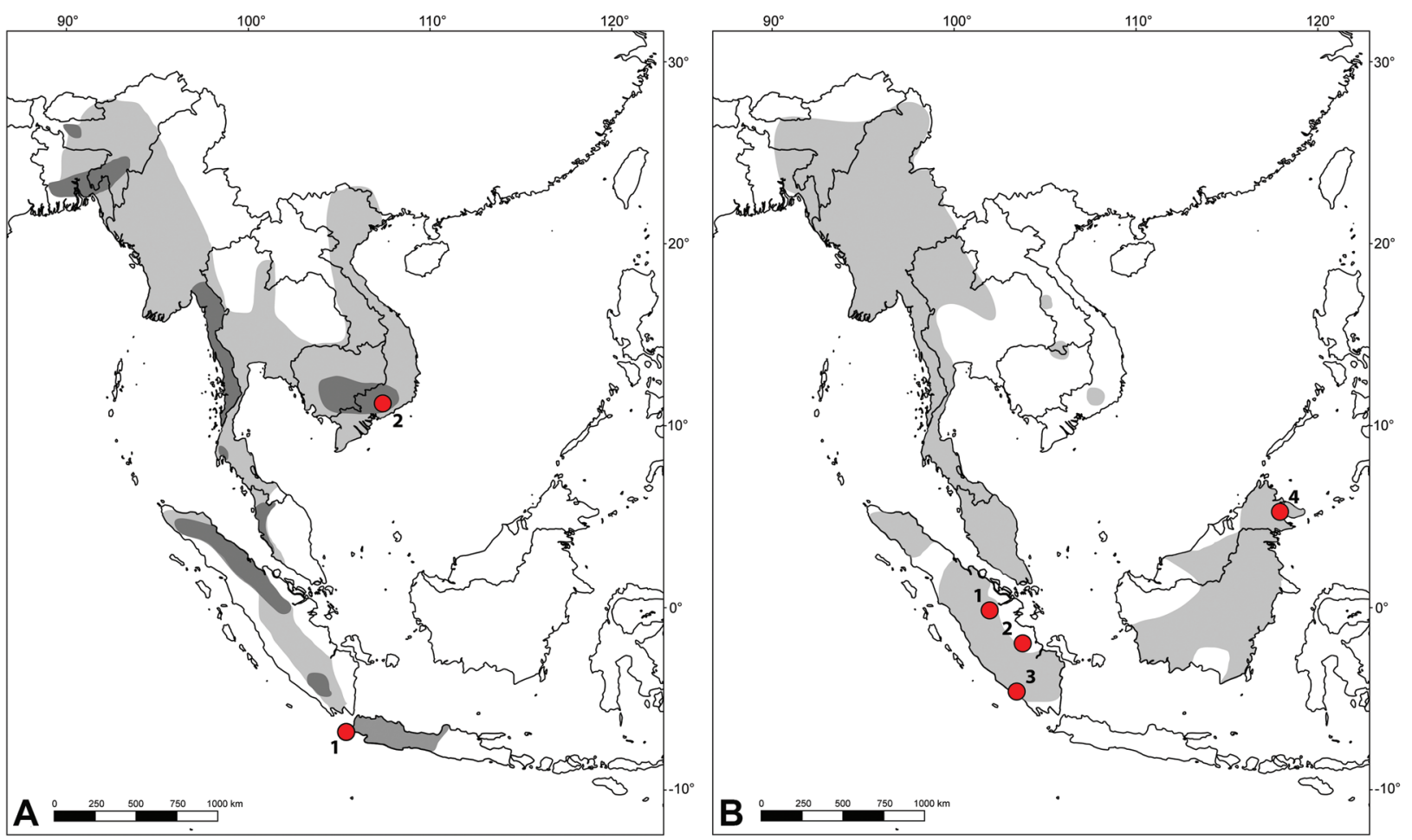

Figure 3. Historical distribution in Southeast Asia and origin of specimens used for molecular investigations of (A) the Javan rhinoceros (Rhinoceros sondaicus), with the only extant location on Java (1) and last extinct one in Vietnam (2), and (B) Sumatran rhinoceros (Dicerorhinus sumatrensis) with locations: 1 - Riau, Sumatra; 2 - Djambi, Sumatra; 3 - Bengkulu, Sumatra; 4 - Sabah, Borneo. Light shaded area: distribution given by Foose and van Strien (1997); dark shaded area: distribution given by Groves and Leslie (2011). 

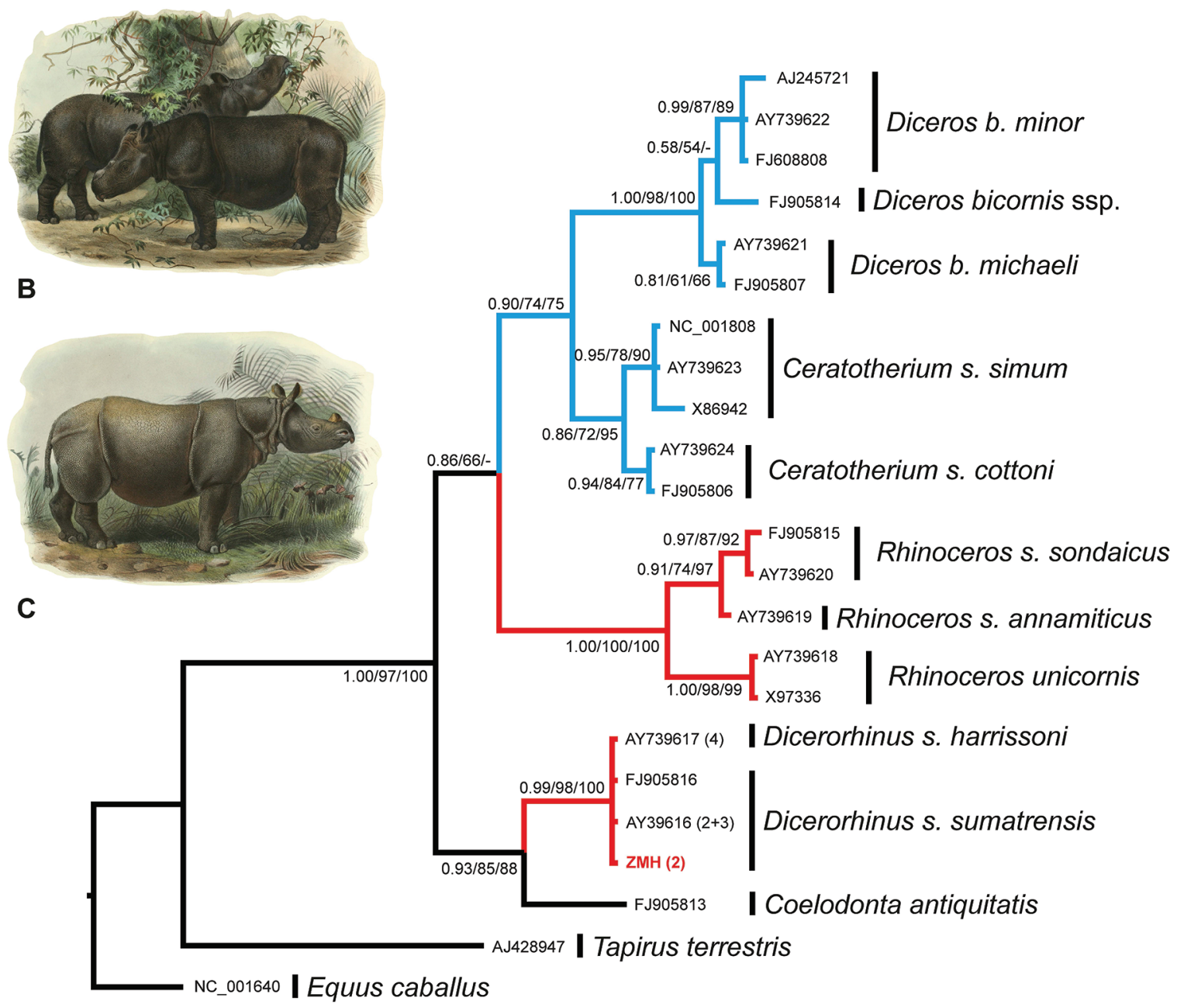

C

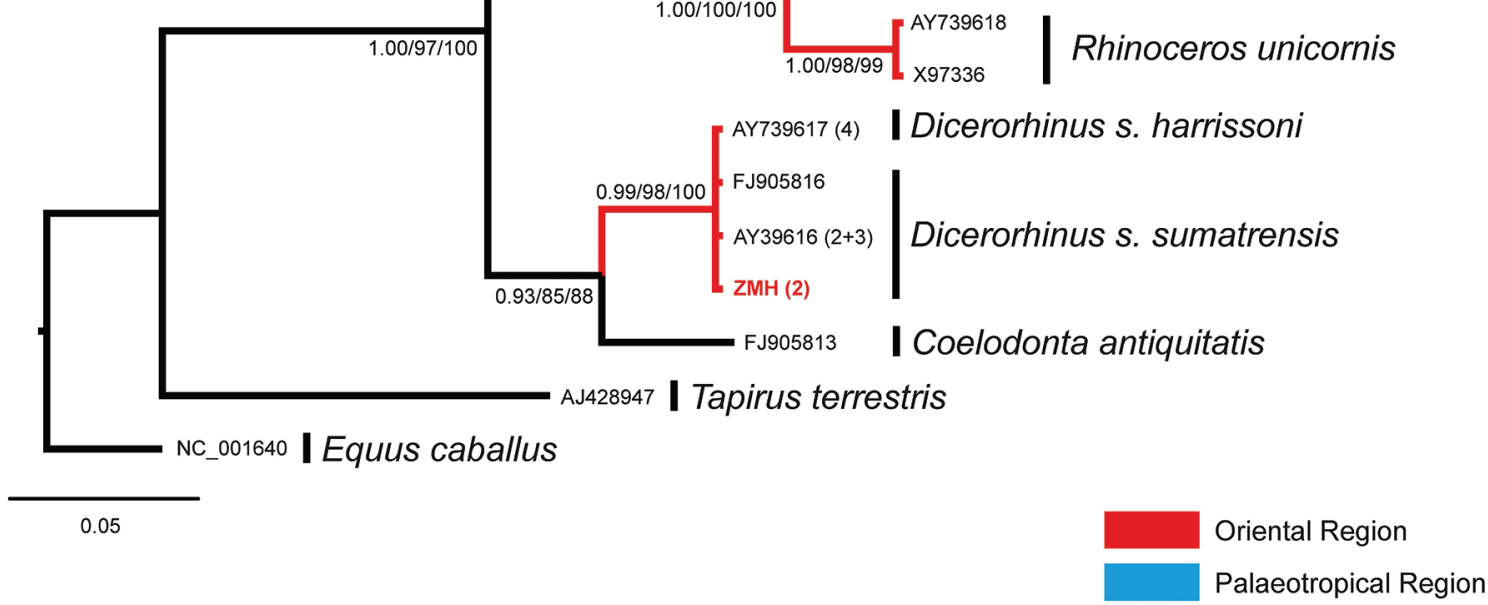

Figure 4. Phylogenetic tree of Rhinocerotidae based on mitochondrial sequences and habitus of Southeast Asian rhinoceroses. A: Bayesian 50\% majority consensus tree based on $12 \mathrm{~S}$ rDNA sequences. Posterior probabilities from Bayesian inference (left) and bootstrap support values ( $\geq 50 \%$ ) from the maximum likelihood (middle) and maximum parsimony (right) analyses are indicated at the nodes. B, C: chromolithographies of the Sumatran rhinoceros (Dicerorhinus sumatrensis; B) and the Javan rhinoceros (Rhinoceros sondaicus; C), modified from Sclater (1876).

with moderately high to high support in the ML and MP analyses but was marginally not supported in the BI analysis (PP: 0.93; BS (ML): 85; BS (MP): 88, Fig. 4). The relationships of the clades including the African rhinoceroses, the clade composed of the Indian and the Javan rhinoceros and the clade including the woolly rhinoceros and the Sumatran rhinoceros were in all three analyses unresolved.

\section{Discussion}

Understanding past and present genetic diversity, in particular in endangered species such as the rhinoceroses, is of great importance for a series of aspects of natural history, evolutionary systematics and conservation. However, as it turned out from several studies even in many museum specimens significant for various reasons the historical context including its provenance often remains unresolved (see Introduction for references to some case studies and discussion).

As direct access to genetic diversity of extinct populations can only be gained from historical specimens housed in natural history collections and museums, exact locality information in concert with resolved species identity becomes even more important, especially when considering the potential of molecular genetic techniques. Given that the only available studies to date, such as e.g. Fernando et al. (2006), sequenced not from actual specimens but from dung samples in addition to one museum specimen of the 
rare Javan rhinoceros $R$. sondaicus of unclear geographical origin, each newly discovered museum specimen is of significance and of conservation importance, as Groenenberg et al. (2012) stated.

Although the distribution and historical ranges of the single-horned Asian rhinoceroses overlap at least in some parts and peripheral areas, not too much information is available on sympatric occurrences. Obviously, both the Sumatran and the Javan rhinoceros co-occurred on the island of Sumatra. Thus, it did not seem unlikely in the first place for the Hamburg rhinoceroses that a specimen each from $R$. sondaicus and D. sumatrensis with identical locality data, viz. Djambi on Sumatra, was reported correctly for the two specimens sold to the ZMH in October 1984 by the Dutch dealer Blonk.

As it is impossible to differentiate the two Sumatran species by the size or shape or other morphological features of the horn alone, no clear-cut identification was possible for long. Thus, only molecular genetic techniques allowed to look into the identification and origin of this delicate and rare museum material.

As in the study of Fernando et al. (2006) our phylogenetic analyses support that the anatomically distinct subspecies $R$. s. annamiticus from Vietnam is also distinguishable from $R$. s. sondaicus from Java by molecular genetic data. These authors also suggested that the Javan and Vietnam populations shared a most recent common ancestor in the Plio-Pleistocene around 2 Mya to 300,000 years ago. However, p-distances between representatives of the nominate subspecies and the specimen assigned to R. s. annamniticus was with $0.9 \%$ rather low. Moreover, Fernando et al. (2006) reported three distinct haplotypes in $R$. s. sondaicus, with two haplotypes even from the very restricted occurrence in the Ujung Kulon National Park in West Java. This finding may be interpreted in view of an originally largely fragmented range on the Southeast Asian mainland and the Sunda Islands and a re-colonization of Western Java following the volcanic eruption and destruction of Krakatau in 1883 (van Strien and Rookmaaker 2010).

Surprisingly, only a single $12 \mathrm{~S}$ rDNA haplotype was found in the Sumatran rhinoceros so far, even the isolated populations from Sumatra and Borneo share the same haplotype with regard to this gene. Whether this is the result of a rapid range extension when sea level was low during the last glacial period or because of the existence of a widespread haplotype in the Sumatran rhinoceros, is difficult to decide because of the low number of individuals sequenced.

The importance of museum samples for the understanding of historic distribution ranges and the loss of genetic diversity is also highlighted in recent studies on the genetic diversity of the African black rhinoceros (Kotzé et al. 2014; Moodley et al. 2017) that examined the rangewide genetic structure of historic and modern populations of the species using both mitochondrial and nuclear datasets. Moodley et al. (2017) described a staggering loss of $69 \%$ of the mitochondrial genetic variation on the basis of recently collected material and historic samples of the black rhinoceros during the $20^{\text {th }}$ century, including the most ancestral lineages that are now absent from modern populations.

Considering that the Bornean subspecies of the Sumatran rhinoceros is on the verge of extinction (Satriastanti 2016) and that the situation for the Sumatran population with an estimated number of about 100 specimens is not considerably better (Nardelli 2014), additional museum samples may help to further elucidate the relationships among now isolated or extinct populations of the Sumatran rhinoceros. To this regard, samples of the extinct mainland subspecies, D. s. lasiotis, would be of great interest as the species may only have comparatively recently (re-)colonized the Greater Sunda Islands of Sumatra and Borneo from the Asian mainland.

\section{Acknowledgements}

We thank the former and active curators of the Mammal collection of the Zoological Museum in Hamburg, Harald Schliemann and Thomas Kaiser, respectively, for information on the catalogue system of the department. We thank two anonymous reviewers for their helpful comments on the manuscript.

\section{References}

Árnason U, Adegoke JA, Gullberg A, Harley EH, Janke A, Kullberg M (2008) Mitogenomic relationships of placental mammals and molecular estimates of their divergences. Gene 421: 37-51. https://doi. org/10.1016/j.gene.2008.05.024

Douzery E, Catzeflis FM (1995) Molecular evolution of the mitochondrial 12S rRNA in Ungulata (Mammalia). Journal of Molecular Evolution 41: 622-636. https://doi.org/10.1007/BF00175821

Fernando P, Polet G, Foead N, Ng LS, Pastorini J, Melnick DJ (2006) Genetic diversity, phylogeny and conservation of the Javan rhinoceros (Rhinoceros sondaicus). Conservation Genetics 7: 439-448. https://doi.org/10.1007/s10592-006-9139-4

Foose TJ, van Strien NJ (1997) Asian rhinos. Status survey and conservation action plan. IUCN/SSC Asian Rhino Specialist Group. IUCN, Gland, Switzerland.

Glaubrecht M (2017) Back to the future - The Centrum für Naturkunde on its way toward re-establishing a Natural History Museum in Hamburg. In: Beck LA (Ed.) Zoological Collections in Germany The Animal Kingdom in its Amazing Plenty at Museums and Universities Springer, Heidelberg, 1-27.

Glaubrecht M, Podlacha K (2010) Freshwater gastropods from early voyages into the Indo-West Pacific: The 'melaniids' (Cerithioidea, Thiaridae) from the French 'La Coquille' circum-navigation, 1822-1825. Zoosystematics and Evolution 86: 185-211. https://doi. org/10.1002/zoos.201000002

Glaubrecht M, Dohle W (2012) Discovering the alternation of generations in salps (Tunicata, Thaliacea): Adelbert von Chamisso's dissertation "De Salpa" 1819 - its material, origin and reception in the ear- 
ly nineteenth century. Zoosystematics and Evolution 88: 317-363. https://doi.org/10.1002/zoos.201200024

Glaubrecht M, Seethaler N, Teßmann B, Koel-Abt K (2013a) The potential of biohistory: Re-discovering Adelbert von Chamisso's skull of an Aleut collected during the "Rurik" Expedition 1815-1818 in Alaska. Zoosystematics and Evolution 89: 317-336. https://doi. org/10.1002/zoos.201300017

Glaubrecht M, Greenwood A, Ebersbach J, Szymansky A, Hönig K, Wiggering B, Gimnich F (2013b) New insights from a lost world. Unlocking the potential of museum collections using historical specimens. Açoreana, Abstracts World Congress of Malacology, Acores, July 2013: 115.

Groenenberg DSJ, de Coursy C, Linnie M, Oosterweghel L (2012) On the identity of the first rhinoceros owned by the Dublin Zoo ( $\dagger 1865)$ : genetic characterisation of a poorly preserved museum specimen. Biology and Environment: Proceedings of the Royal Irish Academy 112B: 285-291. https://doi.org/10.3318/BIOE.2012.18

Groves CP (1967) On the rhinoceroses of south-east Asia. Säugetierkundliche Mitteilungen 15: 221-237.

Groves CP, Leslie DM (2011) Rhinoceros sondaicus (Perissodactyla: Rhinocerotidae). Mammalian Species 43: 190-208. https://doi. org $/ 10.1644 / 887.1$

Groves CP, Fernando P, Robovský J (2010) The sixth rhino: a taxonomic re-assessment of the critically endangered northern white rhinoceros. PloS ONE 5: e9703. https://doi.org/10.1371/journal.pone.0009703

Habel JC, Husemann M, Finger A, Danley PD, Zachos FE (2014) The relevance of time series in molecular ecology and conservation biology. Biological Reviews 89: 484-492. https://doi.org/10.1111/brv.12068 International Rhino Foundation (2010) Annual Report. White Oak.

Kotzé A, Dalton DL, du Troit R, Anderson N, Moodley Y (2014) Genetic structure of the black rhinoceros (Diceros bicornis) from south-eastern Africa. Conservation Genetics 15: 1479-1489. https:// doi.org/10.1007/s10592-014-0632-x

Moodley Y, Russo I-RM, Dalton DL, Antoinette Kotzé A, Muya S, Haubensak P, Bálint B, Munimanda GK, Deimel C, Setzer A, Dicks K, Herzig-Straschil B, Kalthoff DC, Siegismund HR, Robovský J, O'Donoghue P, Bruford MW (2017) Extinctions, genetic erosion and conservation options for the black rhinoceros (Diceros bicornis). Nature Scientific Reports 7: 41417. https://doi.org/10.1038/srep41417

Nardelli F (2014) The last chance for the Sumatran rhinoceros? Pachyderm 55: 43-53.

Neiber MT, Walther F, Hausdorf B (2017) Phylogeny and reclassification of the Caucasigenini radiation from the Caucasus region (Gastropoda, Hygromiidae). Zoologica Scripta. https://doi.org/10.1111/zsc.12259

Ronquist F, Teslenko M, van der Mark P, Ayres DL, Darling A, Höhna S, Larget B, Liu L, Suchard MA, Huelsenbeck JP (2012) MRBAYES 3.2: efficient Bayesian phylogenetic inference and model choice across a large model space. Systematic Biology 61: 539-542. https://doi.org/10.1093/sysbio/sys029

Rookmaaker LC (1982) The type locality of the Java rhinoceros (Rhinoceros sondaicus Desmarest, 1822). Zeitschrift für Säugetierkunde 47: 381-382.
Satriastanti FE (2016) 15 Bornean rhinos discovered in Kalimantan? Mongabay: https://news.mongabay.com/2016/03/a-new-sanctuaryfor-the-sumatran-rhino-in-borneo.

Sclater PL (1876) On the Rhinoceros now or lately living in the Society's Menagerie. Transactions of the Zoological Society of London 9: 645-660, pls 95-99.

Sukumaran J, Holder MT (2010) DENDROPY: a PYTHON library for phylogenetic computing. Bioinformatics 26: 1569-1571. https://doi. org/10.1093/bioinformatics/btq228

Swofford DL (2002) PAUP*. Phylogenetic Analysis Using Parsimony *and other methods. Version 4.0b10. Sinauer Associates, Sunderland.

Titus TA, Larson A (1996) Molecular phylogenetics of desmognathine salamanders (Caudata: Plethodontidae): a reevaluation of evolution in ecology, life history, and morphology. Systematic Biology 45: 451-472. https://doi.org/10.1093/sysbio/45.4.451

Tougard C, Delefosse T, Hanni C, Montgelard C (2001) Phylogenetic relationships of the five extant Rhinoceros species (Rhinocerotidae, Perissodactyla) based on mitochondrial cytochrome $\mathrm{b}$ and $12 \mathrm{~S}$ rRNA genes. Molecular Phylogenetetics and Evolution 19: 34-44. https://doi.org/10.1006/mpev.2000.0903

van Strien NJ, Rookmaaker K (2010) The impact of the Krakatau eruption in 1883 on the population of Rhinoceros sondaicus in Ujung Kulon, with details of rhino observation from 1857 to 1949. Journal of Threatened Taxa 2: 633-638. https://doi.org/10.11609/JoTT. o2267.633-8

Wandeler P, Hoeck PEA, Keller LF (2007) Back to the future: museum specimens in population genetics. Trends in Ecology and Evolution 22: 634-642. https://doi.org/10.1016/j.tree.2007.08.017

Willerslev E, Gilbert MTP, Binladen J, Ho SYW, Campos PF, Ratan A, Tomsho LP, da Fonseca RR, Sher A, Kuznetsova TV, Nowak-Kemp M, Roth TL, Miller W, Schuster SC (2009) Analysis of complete mitochondrial genomes from extinct and extant rhinoceroses reveals lack of phylogenetic resolution. BMC Evolutionary Biology 9: 95. https://doi.org/10.1186/1471-2148-9-95

Xu X, Árnason U (1994) The complete mitochondrial DNA sequence of the horse, Equus caballus: extensive heteroplasmy of the control region. Gene 148: 357-362. https://doi.org/10.1016/03781119(94)90713-7

Xu X, Árnason U (1997) The complete mitochondrial DNA sequence of the white rhinoceros, Ceratotherium simum, and comparison with the mtDNA sequence of the Indian rhinoceros, Rhinoceros unicornis. Molecular Phylogenetetics and Evolution 7: 189-194. https:// doi.org/10.1006/mpev.1996.0385

Xu X, Janke A, Árnason U (1996) The complete mitochondrial DNA sequence of the greater Indian rhinoceros, Rhinoceros unicornis, and the phylogenetic relationship among Carnivora, Perissodactyla, and Artiodactyla (+ Cetacea). Molecular Biology and Evolution 13: 1167-1173. https://doi.org/10.1093/oxfordjournals.molbev. a025681

Zwickl DJ (2006) Genetic algorithm approaches for the phylogenetic analysis of large biological sequence datasets under the maximum likelihood criterion. Ph.D thesis, University of Texas at Austin, Austin. 